\title{
DECADAL CHANGES IN BOMB-PRODUCED RADIOCARBON IN THE PACIFIC OCEAN FROM THE 1990s TO 2000s
}

\author{
Yuichiro Kumamoto ${ }^{1}$ Akihiko Murata • Takeshi Kawano • Shuichi Watanabe • Masao Fukasawa \\ Research Institute for Global Change, Japan Agency for Marine-Earth Science and Technology, 2-15 Natushima-cho, Yoko- \\ suka, Kanagawa 237-0061, Japan.
}

\begin{abstract}
In the 2000s, radiocarbon in dissolved inorganic carbon was measured during 7 revisit cruises along the lines of the World Ocean Circulation Experiment in the Pacific Ocean. Comparison of ${ }^{14} \mathrm{C}$ data along these lines from the 1990s and 2000s revealed decadal changes of ${ }^{14} \mathrm{C}$ concentration in the thermocline, most of which were due to temporal changes in the bomb-produced ${ }^{14} \mathrm{C}$. Vertical profiles and vertical-integrated inventories of the bomb ${ }^{14} \mathrm{C}$ in the subarctic and equatorial regions did not change appreciably. In the southern subtropical region, ${ }^{14} \mathrm{C}$ decreased in the upper thermocline from the surface to $\sim 500 \mathrm{~m}$ depth. In contrast, ${ }^{14} \mathrm{C}$ increased in the lower thermocline below $\sim 500 \mathrm{~m}$ depth. The opposing directions in ${ }^{14} \mathrm{C}$ change resulted in small temporal changes in the total inventory of bomb ${ }^{14} \mathrm{C}$. On the other hand, the water-column inventory significantly decreased in the northwestern subtropical region due to the ${ }^{14} \mathrm{C}$ decrease in the upper thermocline. These decadal changes in bomb ${ }^{14} \mathrm{C}$ indicate that the turnover time of thermocline circulation in the northwestern subtropical region is faster than that in the southern subtropical region, and imply an interbasin transport of bomb ${ }^{14} \mathrm{C}$ from the North Pacific to other basins.
\end{abstract}

\section{INTRODUCTION}

Bomb-produced radiocarbon (bomb ${ }^{14} \mathrm{C}$ ) derived from nuclear weapons tests in the troposphere primarily in the late 1950s and early 1960s is an ideal tracer of air-sea gas exchange and the thermocline circulation in the ocean. All ${ }^{14} \mathrm{C}$ in the ocean has entered from the atmosphere through the carbon dioxide $\left(\mathrm{CO}_{2}\right)$ gas exchange in surface water. The ${ }^{14} \mathrm{C}$ in dissolved inorganic carbon (DIC) in surface water then penetrates into the ocean interior by water advection and diffusion. The first global survey of oceanic ${ }^{14} \mathrm{C}$ during the Geochemical Ocean Section Study (GEOSECS) in the 1970s (Östlund and Stuiver 1980; Stuiver and Östlund 1980, 1983) revealed a global distribution of bomb ${ }^{14} \mathrm{C}$ and the global annual mean of $\mathrm{CO}_{2}$ air-sea exchange rate (Broecker et al. 1985). Meanwhile, Hesshaimer et al. (1994) pointed out that the total amount of bomb ${ }^{14} \mathrm{C}$ determined from the GEOSECS ${ }^{14} \mathrm{C}$ data might be an overestimate. ${ }^{14} \mathrm{C}$ measurements during the World Ocean Circulation Experiment (WOCE) in the 1990s (Key et al. 2004) have also suggested overestimation of the bomb ${ }^{14} \mathrm{C}$ inventory, and, therefore, the air-sea exchange rate derived from the GEOSECS ${ }^{14} \mathrm{C}$ data (Peacock 2004; Naegler and Levin 2006; Sweeney et al. 2007; Naegler 2009).

Although there is uncertainty as to the total inventory of bomb ${ }^{14} \mathrm{C}$ in the whole ocean, the bomb ${ }^{14} \mathrm{C}$ has provided information about the thermocline circulation in the ocean. The GEOSECS data showed that the bomb ${ }^{14} \mathrm{C}$ concentrations at stations in the equatorial regions, high-latitude zones around the Antarctic, and the northern North Pacific were lower than those at stations in the subtropical and northern North Atlantic areas. The explanation for this meridional pattern is that bomb ${ }^{14} \mathrm{C}$ entering regions dominated by upwelling is transported meridionally to areas dominated by downwelling (Broecker et al. 1985, 1995). The oceanic ${ }^{14} \mathrm{C}$ measurements during WOCE in the 1990s indicated that the water-column inventory of bomb ${ }^{14} \mathrm{C}$ increased in the subtropical area and decreased in the subarctic and subantarctic regions between the 1970s and 1990s (Key et al. 2004), which also supports the transport of bomb ${ }^{14} \mathrm{C}$ from high latitudes to temperate regions along the thermocline circulation. In addition, based on water-column inventories of bomb ${ }^{14} \mathrm{C}$, Broecker et al. (1995) suggested that the bomb ${ }^{14} \mathrm{C}$ was transported from the Pacific into the Indian Ocean along the

${ }^{1}$ Corresponding author: Email: kumamoto@jamstec.go.jp.

(c) 2013 by the Arizona Board of Regents on behalf of the University of Arizona

Proceedings of the 21st International Radiocarbon Conference edited by A J T Jull \& C Hatté

RADIOCARBON, Vol 55, Nr 2-3, 2013, p 1641-1650 


\section{Y Kumamoto et al.}

Indonesian Throughflow, which was supported by a model study for bomb ${ }^{14} \mathrm{C}$ in the Pacific Ocean (Rodgers et al. 2000).

In the 2000s, the Japan Agency for Marine-Earth Science and Technology (JAMSTEC) conducted repeat hydrographic cruises along the WOCE Hydrographic Programme (WHP) lines of P01 ( $47^{\circ} \mathrm{N}$ in 2007), $\mathrm{P} 03$ ( $24^{\circ} \mathrm{N}$ in 2005$), \mathrm{P} 06\left(32^{\circ} \mathrm{S}\right.$ in 2003$), \mathrm{P} 10$ ( $149^{\circ} \mathrm{E}$ in 2005$), \mathrm{P} 14\left(179^{\circ} \mathrm{E}\right.$ in 2007$), \mathrm{P} 17 \mathrm{~N}$

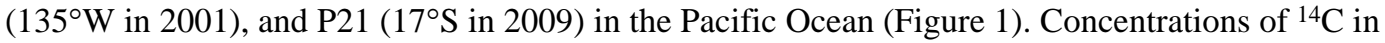
DIC in seawater samples collected during the 7 cruises were measured. Decadal changes in ${ }^{14} \mathrm{C}$ along the WHP-P06 line in the southern subtropical region between 1992 and 2003 have already been discussed by Kumamoto et al. (2007, 2011). A comparison of ${ }^{14} \mathrm{C}$ levels showed that ${ }^{14} \mathrm{C}$ decreased in the upper thermocline from the surface to $\sim 500 \mathrm{~m}$ depth and increased in the lower thermocline below $\sim 500 \mathrm{~m}$ depth, which agrees well with the results from a ${ }^{14} \mathrm{C}$ comparison along a meridional line of the WHP-P16 $\left(152^{\circ} \mathrm{W}\right)$ in the South Pacific (Jenkins et al. 2010). Kumamoto et al. (2011) concluded that bomb ${ }^{14} \mathrm{C}$ slightly increased between 1992 and 2003. Earlier, Kumamoto et al. (2004) reported decadal changes in ${ }^{14} \mathrm{C}$ along the WHP-P17N line in the northeastern subarctic between 1993 and 2001. In this study, we evaluate decadal changes in the bomb ${ }^{14} \mathrm{C}$ along the other 5 WHP lines from the 1990s to 2000s and discuss basin-scale temporal change in bomb ${ }^{14} \mathrm{C}$ in the Pacific Ocean, which will contribute to progress in studies of air-sea gas exchange and thermocline circulation in the ocean.

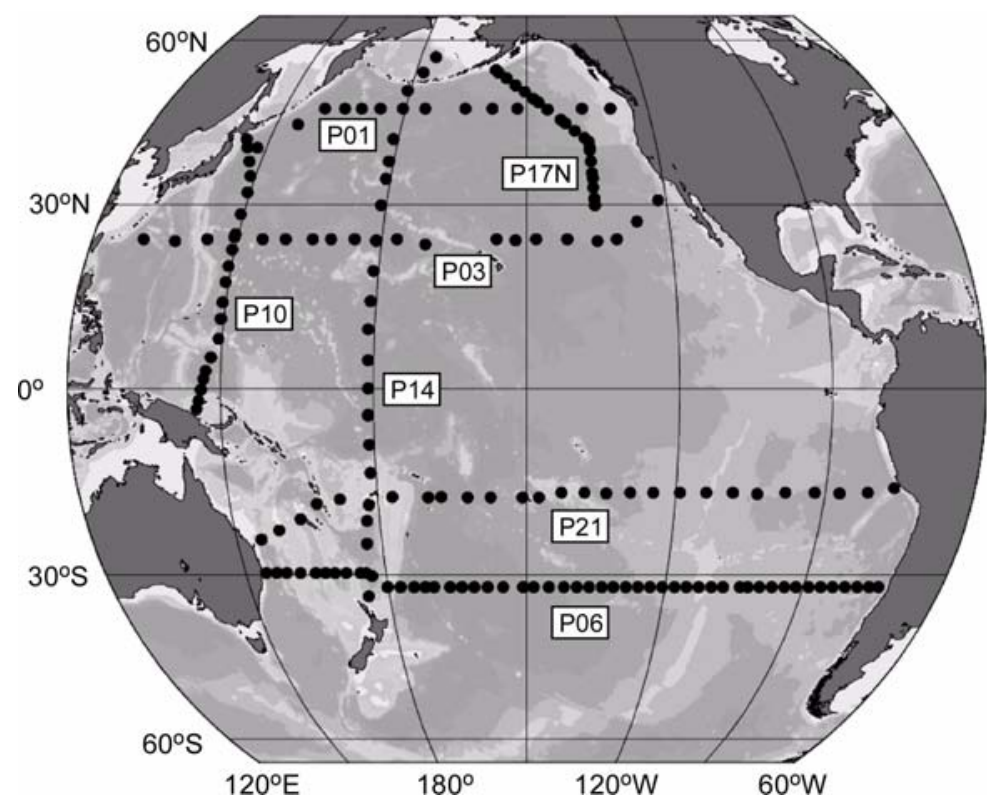

Figure 1 Locations of sampling stations of ${ }^{14} \mathrm{C}$ measurements along the WHP-P01, P03, P06, P10, P14, P17N, and P21 in the Pacific Ocean in the 2000s.

\section{METHODS}

Sampling stations for ${ }^{14} \mathrm{C}$ measurement during the 7 cruises in the Pacific Ocean are shown in Figure 1. Seawater samples were collected from the surface to near bottom layer at 226 stations using 12-L Niskin-X bottles (General Oceanics Inc., USA) equipped with a CTD system (SBE11plus, Sea-Bird Electronics, Inc., USA). The total number of ${ }^{14} \mathrm{C}$ samples was about 7200, including about 500 replicate pairs. The carbon isotopic ratio, ${ }^{14} \mathrm{C} /{ }^{12} \mathrm{C}$, was measured using accelerator 
mass spectrometry (AMS) at the Institute of Accelerator Analysis Ltd in Shirakawa, Japan (using a Pelletron 9SDH-2, National Electrostatics Corporation [NEC], USA), Paleo Labo Co. Ltd in Kiryu, Japan (using a Compact-AMS, NEC, USA), Japan Atomic Energy Agency (JAEA)-Tandetron in Mutsu, Japan (using a 3MV Tandetron AMS, High Voltage Engineering Europa BV, the Netherlands), and National Institute for Environmental Studies (NIES)-TERRA in Tsukuba, Japan (using a Pelletron 15SDH-2, NEC, USA). The results of ${ }^{14} \mathrm{C}$ measurements are expressed as $\Delta^{14} \mathrm{C}$, calculated by the following:

$$
\begin{gathered}
\delta^{14} \mathrm{C}(\%)=\left(\mathrm{R}_{\text {sample }} / \mathrm{R}_{\text {standard }}-1\right) \times 1000 \\
\Delta^{14} \mathrm{C}(\%)=\delta^{14} \mathrm{C}-2\left(\delta^{13} \mathrm{C}+25\right)\left(1+\delta^{14} \mathrm{C} / 1000\right)
\end{gathered}
$$

where $\mathrm{R}_{\text {sample }}$ and $\mathrm{R}_{\text {standard }}$ denote the ${ }^{14} \mathrm{C} /{ }^{12} \mathrm{C}$ ratios of the sample and the international standard, NIST oxalic acid SRM4990-C (HOxII), respectively. $\mathrm{R}_{\text {standard }}$ was corrected for decay since AD 1950 (Stuiver and Polach 1977; Stuiver 1983). $\delta^{13} \mathrm{C}$ is derived from ${ }^{13} \mathrm{C} /{ }^{12} \mathrm{C}$ ratios of the sample and the standard, and measured using a mass spectrometer (Finnigan MAT252, Thermo Fisher Scientific Inc., USA). Finally, the $\Delta^{14} \mathrm{C}$ value was then corrected for ${ }^{14} \mathrm{C}$ decay between the sampling and measurement dates. According to the results from the pairs of replicate samples, the error (standard deviation) of $\Delta^{14} \mathrm{C}$ analyses was calculated to be $4 \%$. The $\delta^{13} \mathrm{C}$ and $\Delta^{14} \mathrm{C}$ data from WHP-P17, P06, P03, and P10 cruises are available at our web page, http://www.jamstec.go.jp/iorgc/ocorp/data/ post-woce.html. Those from the other 3 cruises will be published on the web page soon.

${ }^{14} \mathrm{C}$ in the ocean has 2 sources, bomb ${ }^{14} \mathrm{C}$ produced by the nuclear weapon tests, and natural ${ }^{14} \mathrm{C}$, produced by cosmic rays in the atmosphere. We cannot distinguish the two by using analytical chemistry. The $\Delta^{14} \mathrm{C}$ from nuclear weapons tests (bomb ${ }^{14} \mathrm{C}$ ) was calculated from the difference between the measured and natural $\Delta^{14} \mathrm{C}$ values:

$$
\text { Bomb } \Delta{ }^{14} \mathrm{C}(\%)=\text { Measured } \Delta^{14} \mathrm{C}(\%)-\text { Natural } \Delta^{14} \mathrm{C}(\%)
$$

Observational data of natural ${ }^{14} \mathrm{C}$ (i.e. ${ }^{14} \mathrm{C}$ data from before the start of nuclear weapons tests) are not sufficient for calculation of the bomb ${ }^{14} \mathrm{C}$. In this study, the natural $\Delta^{14} \mathrm{C}(\%)$ values were calculated from the potential alkalinity and dissolved oxygen using an equation from Sweeney et al. (2007). The error in the natural $\Delta^{14} \mathrm{C}$ estimation was calculated to be $\sim 9 \%$ from the standard error of a line fitting between the natural and measured $\Delta^{14} \mathrm{C}$ in layers deeper than $1500 \mathrm{~m}$ where bomb $\Delta^{14} \mathrm{C}$ probably had not yet penetrated. Then, bomb $\Delta^{14} \mathrm{C}$ (\%) was converted to the concentration of bomb ${ }^{14} \mathrm{C}$ (atoms $\mathrm{m}^{-3}$ ). The bomb ${ }^{14} \mathrm{C}$ error was calculated to be $\sim 2 \times 10^{10}$ atoms $\mathrm{m}^{-3}$, including errors due to ${ }^{14} \mathrm{C}$ measurement and natural $\Delta^{14} \mathrm{C}$ calculation. The total error in the vertical water-column inventory of bomb ${ }^{14} \mathrm{C}$ (atoms $\mathrm{m}^{-2}$ ) was $\sim 10 \times 10^{12}$ atoms $\mathrm{m}^{-2}$. These errors are the lower limits since inherent uncertainties in the natural $\Delta^{14} \mathrm{C}$ calculation were not taken into account.

\section{RESULTS}

Figure 2 shows 3 zonal and 4 meridional sections of bomb $\Delta^{14} \mathrm{C}$ (\%) from the surface to $1600 \mathrm{~m}$ depth along the WHP-P01, P03, P06, P10, P14, P17N, and P21 lines. The longest meridional section along the WHP-P14 line clearly indicates that bomb ${ }^{14} \mathrm{C}$ accumulated in the northern and southern subtropical regions. In addition, the vertical profiles in the subtropical regions are characterized by subsurface maxima between about 200 and $300 \mathrm{~m}$ depths, which also can be identified in the zonal sections along the WHP-P03, P06, and P21 lines. Along the zonal sections of WHP-P21, the upwelling of deeper waters in which concentration of bomb ${ }^{14} \mathrm{C}$ is low resulted in shallower penetration depths of bomb ${ }^{14} \mathrm{C}$ at the eastern stations than those at the western stations. The shallow pen- 


\section{Y Kumamoto et al.}

etration was also observed at the easternmost stations both along the WHP-P03 and WHP-P06 lines. However, bomb ${ }^{14} \mathrm{C}$ along the WHP-P06 line in the southern subtropical region was accumulated at stations in the eastern part of the section. These distributions of bomb ${ }^{14} \mathrm{C}$ are primarily controlled by ocean circulation rather than air-sea gas exchange (Graven et al. 2012).

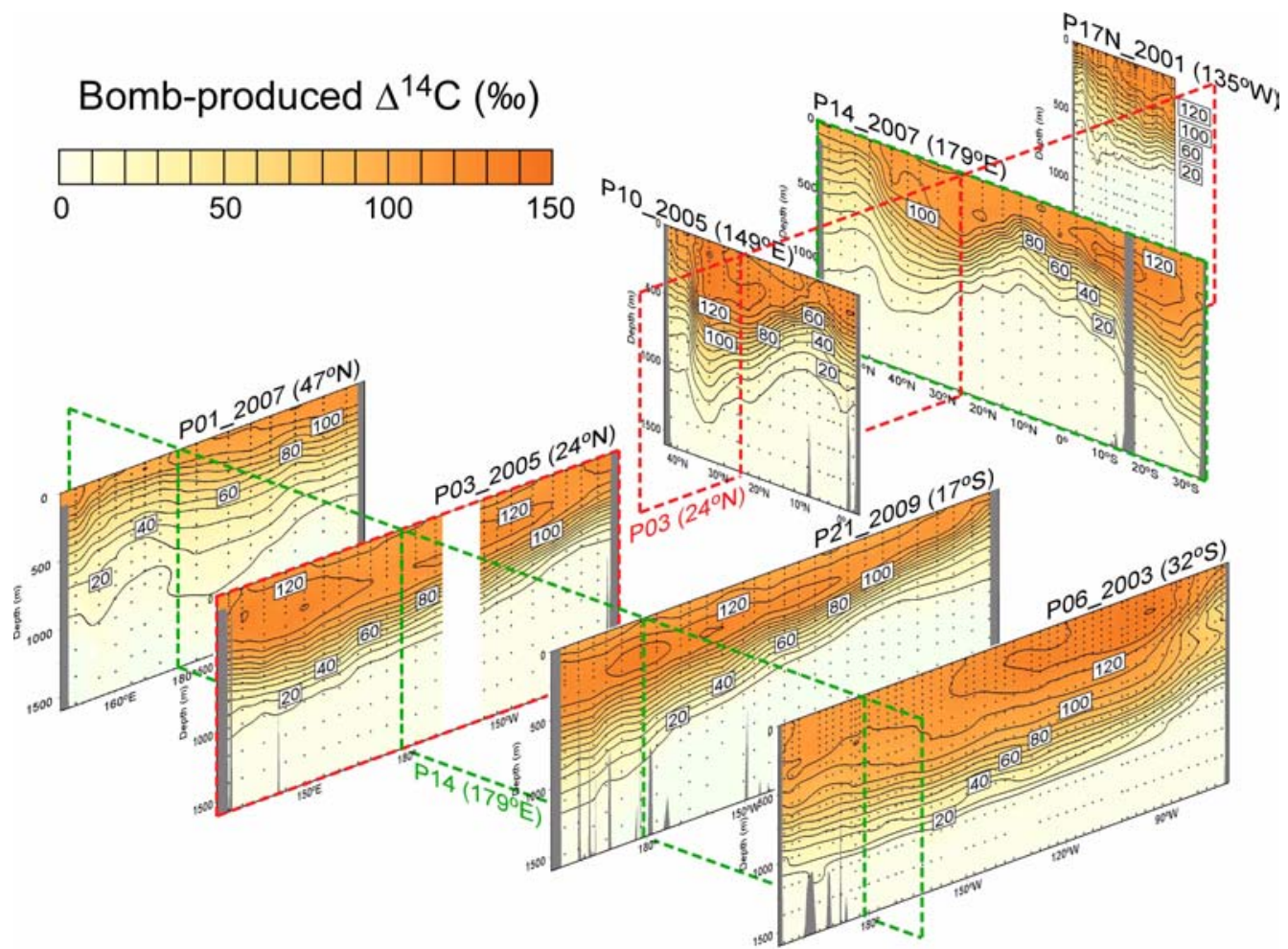

Figure 2 Zonal and meridional sections of bomb $\Delta{ }^{14} \mathrm{C}$ values (\%) along the WHP-P01, P03, P06, P10, P14, P17N, and P21 lines in the Pacific Ocean in the 2000s.

The vertical water-column inventory of ${ }^{14} \mathrm{C}$ (atoms $\mathrm{m}^{-2}$ ) was calculated from the concentration of ${ }^{14} \mathrm{C}$ (atoms $\mathrm{m}^{-3}$ ) derived from $\Delta^{14} \mathrm{C}(\%)$. Figure 3 shows the inventory of bomb ${ }^{14} \mathrm{C}$ at each station along the 4 zonal WHP lines in the 2000s. For comparison, we also show the inventories in the 1990s at the nearest stations, which is from historical ${ }^{14} \mathrm{C}$ data obtained during cruises of the WHP (Key et al. 2004), the North Pacific Carbon Cycle Study (Watanabe et al. 1999), and JAMSTEC (Kumamoto et al. 2002). Kumamoto et al. (2011) pointed out that the basin-scale mean of the inventory along the WHP P06 line in the southern subtropical region slightly increased probably due to increases at stations in the eastern part of the line. However, there were a few stations where a significant increase in the inventory was observed between the 1990s and 2000s (Figure 3d). Along the other 3 zonal lines, significant changes in the inventory were not observed except for decreases at stations in the western part of the WHP-P03 line (Figure 3b) and in the center of the WHP-P21 line (Figure 3c).

The decadal decrease in bomb ${ }^{14} \mathrm{C}$ inventory was also observed at stations along the 3 meridional lines (Figure 4). Along the WHP-P10 line in the western North Pacific, the inventory decreased significantly at stations in the subtropical region $\left(20 \sim 30^{\circ} \mathrm{N}\right)$ between 1993 and 2005 (Figure 4c), which 


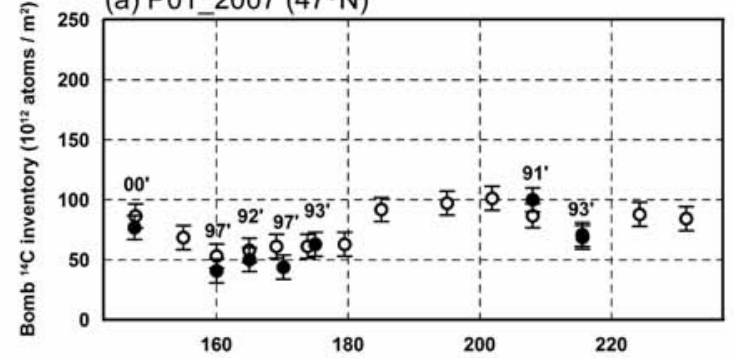

(b) P03_2005 (24ㅇN)
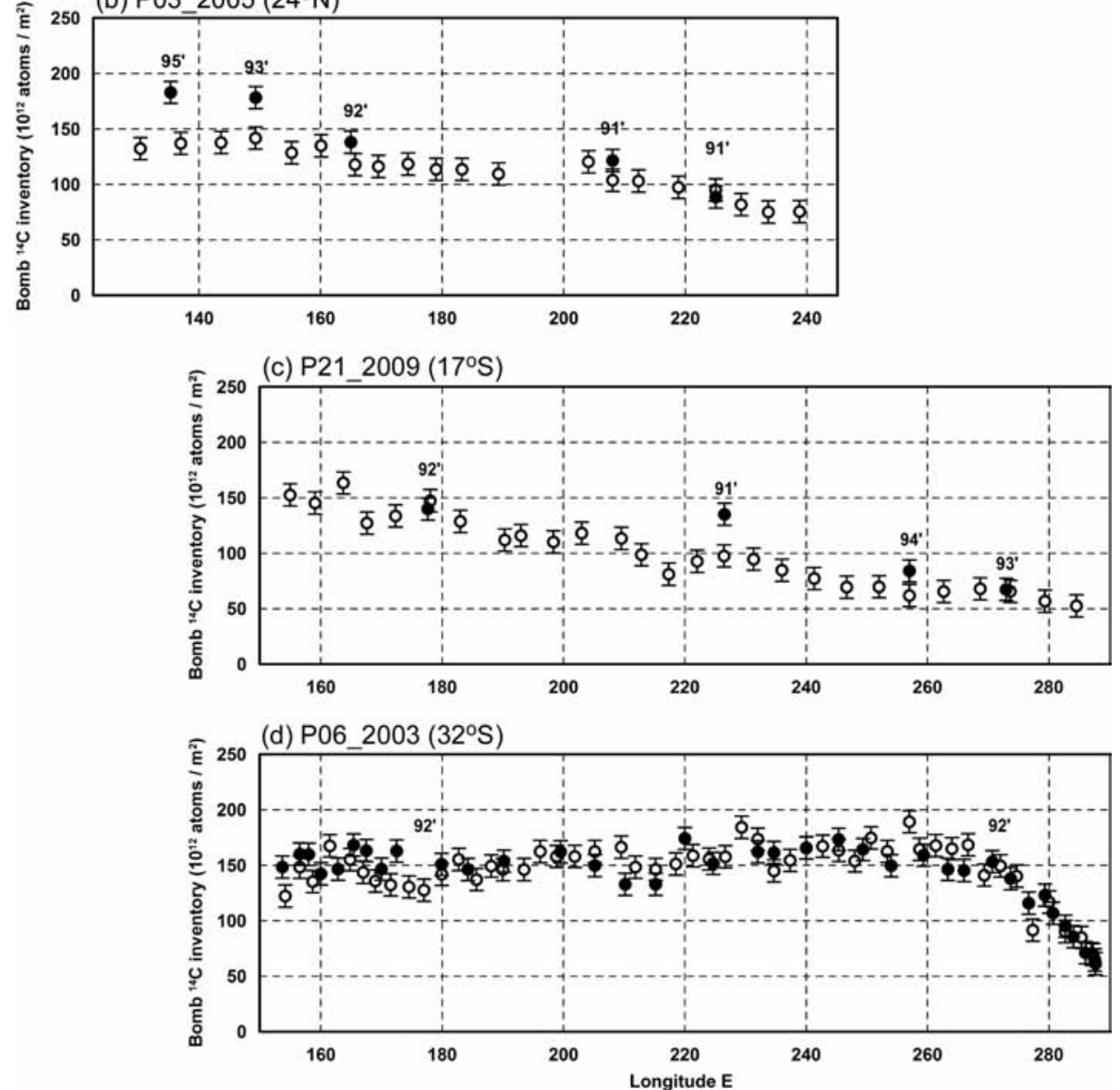

Figure 3 Water-column inventory of bomb ${ }^{14} \mathrm{C}\left(10^{12}\right.$ atoms $\left.\mathrm{m}^{-2}\right)$ at stations along the zonal WHP lines of P01 (a), P03 (b), P21 (c), and P06 (d) in the 2000s (open circles) and 1990s (closed circles). Two-digit numbers indicate the year $\mathrm{AD}$ when the latter were obtained. Error of each inventory was calculated to be about $10 \times 10^{12}$ atoms $\mathrm{m}^{-2}$.

agrees well with results from the western region of the WHP-P03 line during nearly the same period (Figure $3 b)$. The decadal decrease of inventory also appeared in the subtropical region of the North Pacific $\left(30^{\circ} \mathrm{N}\right)$ along the WHP-P14 line (Figure $\left.4 \mathrm{~b}\right)$. It should be noted that the decline of bomb ${ }^{14} \mathrm{C}$ was not obvious in the subtropical region of the South Pacific, which also agrees with what was observed along the WHP-P06 line (Figure 3d). 

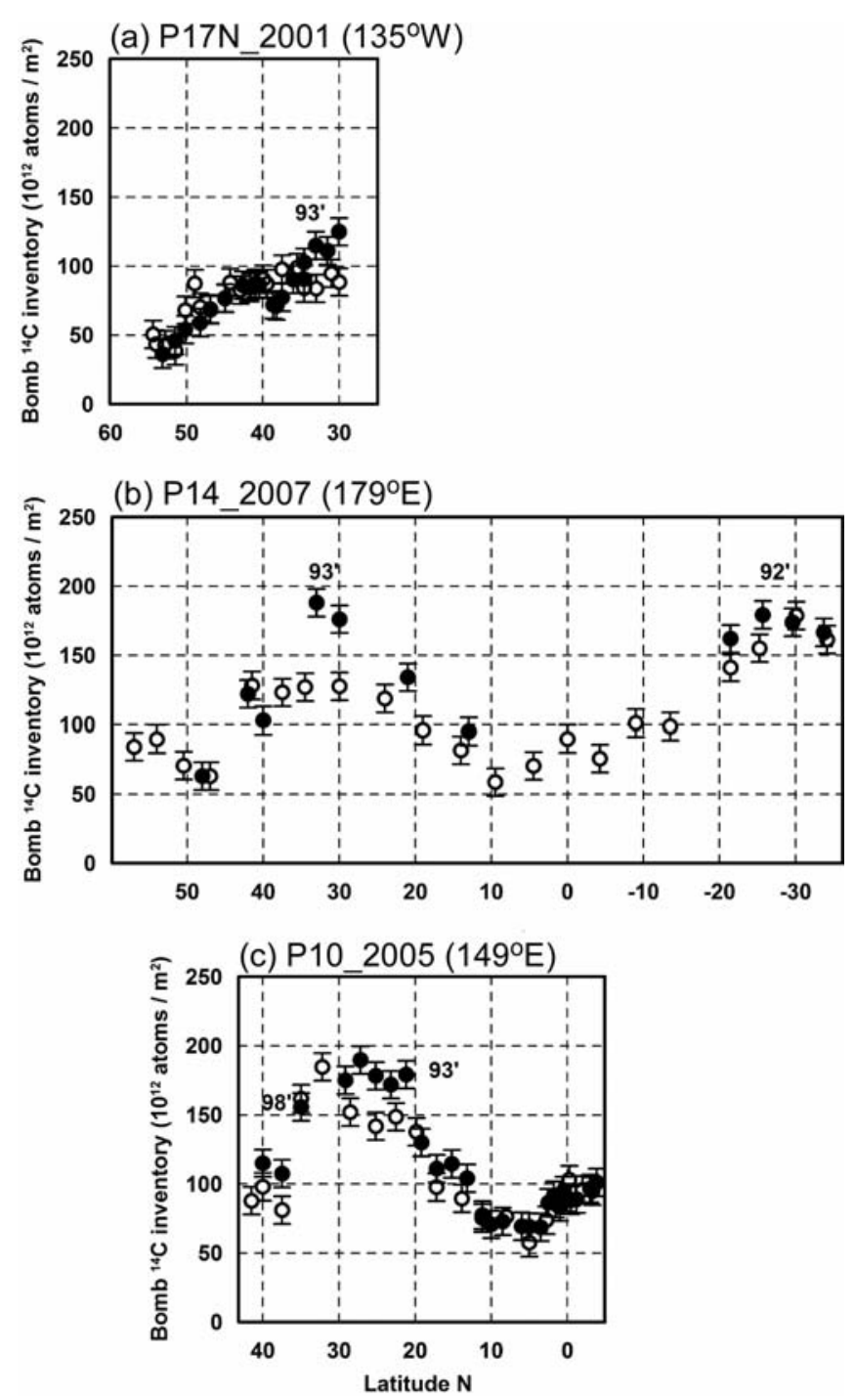

Figure 4 Same as Figure 3 but for stations along the meridional WHP lines of P17N (a), P14 (b), and P10 (c).

We compared vertical profiles of $\Delta^{14} \mathrm{C}$ (\%) from the 1990s to 2000s (Figure 5). If the temporal variation in natural ${ }^{14} \mathrm{C}$ is small, the difference in the ${ }^{14} \mathrm{C}$ vertical profile between the 1990s and 2000s would indicate a decadal change in bomb ${ }^{14} \mathrm{C}$ only. At stations in the western subarctic and western equatorial regions, the difference in the vertical profile of $\Delta^{14} \mathrm{C}$ was small (Figures $5 \mathrm{a}$ and $5 \mathrm{~b}$ ). These small differences in the vertical $\Delta^{14} \mathrm{C}$ profile resulted in small decadal changes in the bomb ${ }^{14} \mathrm{C}$ inventory in the western subarctic (Figure 3a) and western equatorial (Figure 4c) regions. In contrast, as pointed out by Kumamoto et al. (2011), in the southern subtropical region $\Delta^{14} \mathrm{C}$ decreased in the upper thermocline from the surface to $\sim 500 \mathrm{~m}$ depth and increased in the lower thermocline below $\sim 500 \mathrm{~m}$ depth (Figures $5 \mathrm{c}$ and $5 \mathrm{~d}$ ), which also resulted in a small decadal change in the watercolumn inventory (Figures $3 \mathrm{~d}$ and $4 \mathrm{~b}$ ). In the northwestern subtropical region, $\Delta^{14} \mathrm{C}$ decreased in the upper thermocline (Figures 5e, 5f, 5g, and 5h) as same it did in the southern subtropical region (Fig- 
Bomb-Produced ${ }^{14} \mathrm{C}$ in the Pacific, 1990s to 2000s
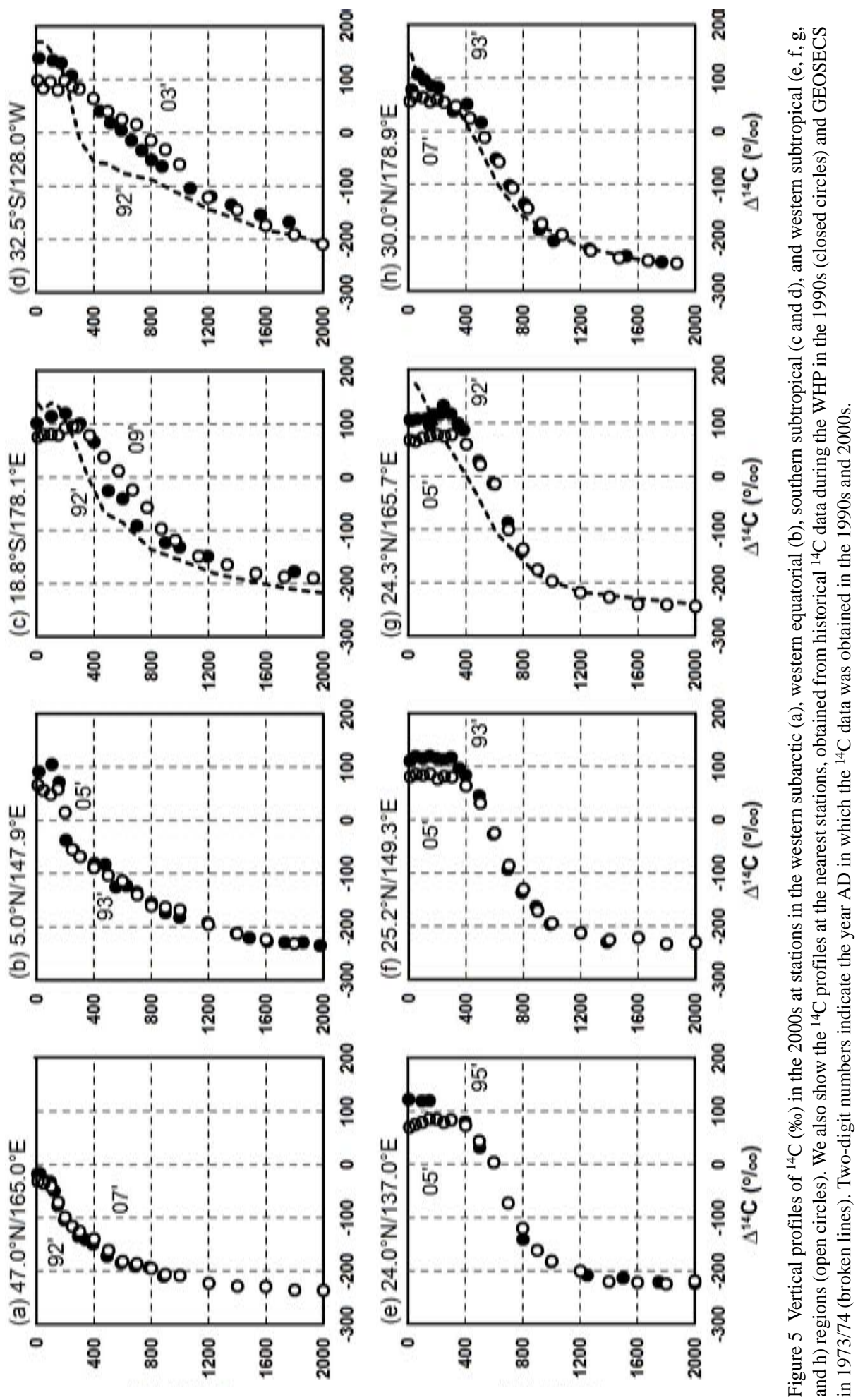


\section{Y Kumamoto et al.}

ures $5 \mathrm{c}$ and $5 \mathrm{~d}$ ). In the lower thermocline, however, the decadal change in the $\Delta^{14} \mathrm{C}$ vertical profile was small. Therefore, the vertical inventory of bomb ${ }^{14} \mathrm{C}$ significantly declined in the northwestern subtropical region between the 1990s and 2000s (Figures 3b, 4b, and 4c).

We also compared dissolved oxygen concentrations along the 7 WHP lines in order to estimate temporal changes in the natural ${ }^{14} \mathrm{C}$ that was calculated using concentrations of dissolved oxygen, nutrients, and alkalinity. Along the WHP-P03, P06, P10, and P14 lines, large oxygen changes were not observed between the late 1980s/early 1990s and 2000s (Kouketsu et al. 2010; Kumamoto et al. 2011). Moreover, temporal changes in oxygen concentration at stations along the WHP-P21 line and western stations along the WHP-P01 line between the 1990s and 2000s were small (not shown). These small changes in oxygen content imply that the temporal changes in natural ${ }^{14} \mathrm{C}$ were negligible at most of the stations in the Pacific Ocean between the 1990s and 2000s. A direct comparison of $\Delta{ }^{14} \mathrm{C}^{14} \mathrm{C}$ at stations along the WHP-17N line showed a decrease in $\Delta^{14} \mathrm{C}$ between 1993 and 2001 (Kumamoto et al. 2004). The small temporal changes in bomb ${ }^{14} \mathrm{C}$ inventory along the WHP-17N line (Figure 4a) therefore indicate decreases in the natural ${ }^{14} \mathrm{C}$ due to a decrease of oxygen concentration. In fact, oxygen concentration significantly decreased in the upper thermocline at these stations along the WHP-P17 line between 1993 and 2001 (Kumamoto et al. 2004).

\section{DISCUSSION}

New oceanic ${ }^{14} \mathrm{C}$ data obtained in the 2000s revealed basin-scale temporal changes in bomb ${ }^{14} \mathrm{C}$ in the Pacific Ocean between the 1990s and 2000s. In the southern subtropical region, the decrease in the upper thermocline and the increase in the lower thermocline canceled out each other and resulted in a small decadal change in the vertical inventory (Figure 3d). The small temporal variation in the ${ }^{14} \mathrm{C}$ vertical profile caused a small change in the vertical inventory of bomb ${ }^{14} \mathrm{C}$ in the western equatorial region (Figure 4c). The behavior of bomb ${ }^{14} \mathrm{C}$, however, is uncertain in the eastern equatorial region where $\Delta^{14} \mathrm{C}$ was not measured in the 2000s. Bomb ${ }^{14} \mathrm{C}$ decreased in the northwestern subtropical region, approximately $20-30^{\circ} \mathrm{N}$ and $130-180^{\circ} \mathrm{E}$ (Figures 3b, 4b, and 4c). However, the change in the eastern subtropical region of the North Pacific is uncertain again due to limited $\Delta^{14} \mathrm{C}$ data in the 2000s. Decadal variation in bomb ${ }^{14} \mathrm{C}$ in the subtropical and equatorial regions in the eastern North Pacific will be discussed using ${ }^{14} \mathrm{C}$ measurements from the US Global Ocean Carbon and Repeat Hydrography program, which re-occupied the WHP lines P02 $\left(30^{\circ} \mathrm{N}\right), \mathrm{P} 16\left(152^{\circ} \mathrm{W}\right)$, and P18 $\left(103^{\circ} \mathrm{W}\right)$.

In the subarctic region of the North Pacific, the decadal changes in bomb ${ }^{14} \mathrm{C}$ inventory were small (Figures 3a, 4a, and 4b). In the eastern subarctic region, however, $\Delta^{14} \mathrm{C}$ decreased significantly due to the decrease in natural ${ }^{14} \mathrm{C}$ (Kumamoto et al. 2004). Kouketsu et al. (2010) reported a decadalscale oscillation of oxygen concentration in the upper thermocline along the WHP-P01 line in the subarctic region, which was probably derived from climate variability in the North Pacific (Deutsch et al. 2006; McKinley et al. 2006). Evaluating the bomb ${ }^{14} \mathrm{C}$ inventory in the subarctic region in the North Pacific involves a larger uncertainty due to the assumption made with the separation method between the natural and bomb ${ }^{14} \mathrm{C}$.

The difference in decadal changes of vertical-integrated bomb ${ }^{14} \mathrm{C}$ between the northwestern and southern subtropical regions simply indicates that the turnover time of lower thermocline circulation in the northwestern subtropical region is faster than that in the southern subtropical region. The bomb ${ }^{14} \mathrm{C}$ concentration in the atmosphere was highest in the mid-1960s. In surface seawater, the bomb ${ }^{14} \mathrm{C}$ peak appeared in the mid-1970s, about $10 \mathrm{yr}$ after the atmospheric peak because of the time required for the air-sea gas exchange. Then, the bomb ${ }^{14} \mathrm{C}$ peak penetrated into the ocean inte- 
rior gradually. Therefore, the increasing trend in bomb ${ }^{14} \mathrm{C}$ between the 1970s, 1990s, and 2000s in the lower thermocline of the southern subtropical region (Figures $5 \mathrm{c}$ and $5 \mathrm{~d}$ ) indicates that the bomb ${ }^{14} \mathrm{C}$ peak has not yet reached there. On the other hand, the ${ }^{14} \mathrm{C}$ increase between the 1970s and 1990s and the small change between the 1990s and 2000s in the lower thermocline of the northwestern subtropical region (Figures 5g and 5h) imply that the peak passed through there between the 1970s and 1990 s or 2000 s.

The asymmetry in the turnover time derived from bomb ${ }^{14} \mathrm{C}$ is consistent with a horizontal distribution of "water age" in the Pacific Ocean. Fine et al. (2001) reported "water age" estimated from chlorofluorocarbon concentration in the lower thermocline. The "water age" map clearly shows that the "younger" waters spread more equatorward in the western North Pacific than those in the South Pacific and eastern North Pacific, which suggests that the Sea of Okhotsk is an important location for ventilation processes of intermediate waters in the North Pacific (Warner et al. 1996). It is worth noting that the meridional overturning circulation in the Pacific Ocean thermocline varied on a decadal timescale (McPhaden and Zhang 2002). A spinning up of the circulation from the mid 1990s to early 2000s (McPhaden and Zhang 2004) might accelerate the asymmetry between the North and South Pacific Oceans.

Decadal change in the total inventory of bomb ${ }^{14} \mathrm{C}$ in the entire Pacific Ocean between the 1990 s and 2000s is still uncertain. In the North Pacific basin, however, the total bomb ${ }^{14} \mathrm{C}$ inventory could have decreased due to the decrease in the western subtropical region. If so, the lost bomb ${ }^{14} \mathrm{C}$ in the North Pacific basin should have been transported into other basins. One of the possible ways is an interbasin transport from the North Pacific Ocean to the Indian Ocean, namely, the Indonesian Throughflow. A synthesis of the decadal change of bomb ${ }^{14} \mathrm{C}$ inventory in the Pacific Ocean between the 1990s and 2000s could provide a quantitative determination of the Indonesian Throughflow.

\section{ACKNOWLEDGMENTS}

We thank the crew of the R/V Mirai and the staff of Marine Works Japan, Ltd. for their help during sample collection and preparation. This work was partially supported by a Ministry of Education, Culture, Sports, Science and Technology (MEXT) of Japan Grant-in-Aid for Science Research (KAKENHI 18310017) and the Common-Use Facility Program of JAEA (2007A-F03, 2007B-F05, 2008A-F02, 2009A-F05, 2010A-F06, and 2011A-F04). Figures 1 and 2 were prepared using Ocean Data View (Schlitzer 2012).

\section{REFERENCES}

Broecker WS, Peng TH, Östlund GH, Stuiver M. 1985. The distribution of bomb radiocarbon in the ocean. Journal of Geophysical Research 90(C4):6953-70.

Broecker WS, Sutherland S, Smethie W, Peng T-H, Östlund GH. 1995. Oceanic radiocarbon: separation of the natural and bomb components. Global Biogeochemical Cycles 9(2):263-88.

Deutsch C, Emerson S, Thompson L. 2006. Physical-biological interactions in North Pacific oxygen variability. Journal of Geophysical Research 111: C09S90, doi:10.1029/2005JC003179.

Fine RA, Maillet KA, Sullivan KF, Willey D. 2001. Circulation and ventilation flux of the Pacific Ocean. Journal of Geophysical Research 106(C10):22,15978.

Graven HD, Gruber N, Key R, Khatiwala S, Giraud X.
2012. Changing controls on oceanic radiocarbon: new insights on shallow-to-deep ocean exchange and anthropogenic $\mathrm{CO}_{2}$ uptake. Journal of Geophysical Research 117: C10005, doi:10.1029/2012JC008074.

Hesshaimer V, Heimann M, Levin I. 1994. Radiocarbon evidence for a smaller oceanic carbon dioxide sink than previously believed. Nature 370(6486):201-3.

Jenkins WJ, Elder KL, McNichol AP, von Reden K. 2010. The passage of the bomb radiocarbon pulse into the Pacific Ocean. Radiocarbon 52(3):1182-90.

Key RM, Kozyr A, Sabine CL, Lee K, Wanninkhof R, Bullister JL, Feely RA, Millero FJ, Mordy C, Peng TH. 2004. A global ocean carbon climatology: results from Global Data Analysis Project (GLODAP). Global Biogeochemical Cycles 18: GB4031, doi:101029/ 2004GB002247. 


\section{Y Kumamoto et al.}

Kouketsu S, Fukasawa M, Sasano D, Kumamoto Y, Kawano T, Uchida H, Doi T. 2010. Changes in water properties around North Pacific intermediate water between the 1980s, 1990s and 2000s. Deep-Sea Research II 57(13-14):1177-87.

Kumamoto Y, Murata A, Saito C, Honda MC, Kusakabe M. 2002. Bomb radiocarbon invasion into the northwestern North Pacific. Deep-Sea Research II 49(2425):5339-51.

Kumamoto Y, Murata A, Watanabe S, Fukasawa M, Yoneda M, Shibata Y, Morita M. 2004. Preliminary results of radiocarbon measurement during the WHP P17N re-visit cruise in 2001. Nuclear Instruments and Methods in Physics Research B 223-224:441-5.

Kumamoto Y, Murata A, Watanabe S, Fukasawa M. 2007. Decadal changes of bomb radiocarbon in the subtropical South Pacific Ocean between 1992 and 2003. Radiocarbon 49(2):937-45.

Kumamoto Y, Murata A, Watanabe S, Fukasawa M. 2011. Temporal and spatial variations in bomb radiocarbon along BEAGLE2003 lines-revisits of WHP P06, A10, and I03/I04 in the Southern Hemisphere oceans. Progress in Oceanography 89(1-4):49-60.

McKinley GA, Takahashi T, Buitenhuis E, Chai F, Christian JR, Doney SC, Jiang MS, Lindsay K, Moore JK, Le Quéré C, Lima I, Murtugudde R, Shi L, Wetzel P. 2006. North Pacific carbon cycle response to climate variability on seasonal to decadal timescales. Journal of Geophysical Research 111: C07S06, doi:10.1029/ 2005JC003173.

McPhaden MJ, Zhang D. 2002. Slowdown of the meridional overturning circulation in the upper Pacific Ocean. Nature 415(6872):603-8.

McPhaden MJ, Zhang D. 2004. Pacific Ocean circulation rebounds. Geophysical Research Letters 31: L18301, doi:10.1029/2004GL020727.

Naegler T. 2009. Reconciliation of excess ${ }^{14} \mathrm{C}$-constrained global $\mathrm{CO}_{2}$ piston velocity estimates. Tellus $B$
61(2):372-84.

Naegler T, Levin I. 2006. Closing the global radiocarbon budget 1945-2005. Journal of Geophysical Research 111: D12311, doi:10.1029/2005JD006758.

Östlund HG, Stuiver M. 1980. GEOSECS Pacific radiocarbon. Radiocarbon 22(1):25-53.

Peacock S. 2004. Debate over the ocean bomb radiocarbon sink: closing the gap. Global Biogeochemical $\mathrm{Cy}$ cles 18: GB2202, doi:10.1029/2003GB002211.

Rodgers KB, Schrag DP, Cane MA, Naik NH. 2000. The bomb ${ }^{14} \mathrm{C}$ transient in the Pacific Ocean. Journal Geophysical Research 105(C4):8489-512.

Schlitzer R. 2012. Ocean Data View. URL: <http:// odv.awi.de/en/home/>

Stuiver M. 1983. International agreements and the use of the new oxalic acid standard. Radiocarbon 25(2):793-

Stuiver M, Östlund HG. 1980. GEOSECS Atlantic radiocarbon. Radiocarbon 22(1):1-24.

Stuiver M, Östlund HG. 1983. GEOSECS Indian Ocean and Mediterranean radiocarbon. Radiocarbon 25(1): $1-29$.

Stuiver M, Polach HA. 1977. Discussion: reporting of ${ }^{14} \mathrm{C}$ data. Radiocarbon 19(3):355-63.

Sweeney C, Gloor E, Jacobson AJ, Key RM, McKinley G, Sarmiento JL, Wanninkhof R. 2007. Constraining global air-sea gas exchange for $\mathrm{CO}_{2}$ with recent bomb ${ }^{14} \mathrm{C}$ measurements. Global Biogeochemical Cycles 21: GB2015, doi:101029/2006GB002784.

Warner MJ, Bullister JL, Wisegarver DP, Gammon RH, Weiss RF. 1996. Basin-wide distributions of chlorofluorocarbons CFC-11 and CFC-12 in the North Pacific: 1985-1989. Journal Geophysical Research 101(C9):20,525-42.

Watanabe YW, Ono T, Harada K, Fukasawa M. 1999. A preliminary study of oceanic bomb radiocarbon inventory in the North Pacific during the last two decades. Journal of Oceanography 55(6):705-16. 